\title{
Influence of Different Methods and Levels of Irrigation on Photosynthetic Pigments in Relation to Yield of Oil Palm (Elaeis guineensis Jacq.)
}

\author{
M. Chandra Surya Rao ${ }^{1 *}$, B.N. Rao ${ }^{2}$, V. Vijaya Bhaskar ${ }^{1}$, K. Suresh ${ }^{2}$ and S. Kalpana ${ }^{2}$ \\ ${ }^{1}$ Department of Horticulture, Dr. Y.S.R. Horticultural University, Venkataramannagudem, \\ West Godavari district, A.P - 534 101, India \\ ${ }^{2}$ ICAR-Indian Institute of Oil Palm Research, Pedavegi, West Godavari district, \\ A.P - 534 450, India \\ *Corresponding author
}

\begin{abstract}
Keywords
Oil palm, Crop factor,

Chlorophyll, Male and

female inflorescences,

FFBs

Article Info

Accepted:

04 January 2018

Available Online:

10 February 2018 Indian Institute of Oil Palm Research, Pedavegi, Andhra Pradesh with different methods and levels of irrigation water using crop factors to find out their influence on the photosynthetic pigments in relation to yield of fresh fruit bunches. Significantly highest chlorophyll-a $\left(2.38 \mathrm{mgg}^{-1}\right)$, total chlorophyll $\left(2.73 \mathrm{mgg}^{-1}\right)$ were found with drip method of irrigation. Among the levels of irrigation water using crop factor 0.8 has recorded significantly highest chlorophyll-a $\left(2.33 \mathrm{mgg}^{-1}\right)$. Significantly highest chlorophyll-a (2.66 $\left.\mathrm{mgg}^{-1}\right)$, total chlorophyll $\left(3.11 \mathrm{mgg}^{-1}\right)$ and total carotenoids content $\left(0.17 \mathrm{mgg}^{-1}\right)$ were observed with drip method of irrigation is crop factor 0.6. Application of irrigation water through drip method of irrigation is crop factor 0.8 recorded highest number of leaves (25.83), highest number of female inflorescences (7.16) and lowest number of male inflorescences (5.12) produced thereby contributed to the increased production of number of fresh fruit bunches (7.16), total weight of FFBs (148.44 kg/palm/year) thus increased FFB yield (21.23 t/ha).
\end{abstract}

\section{A B S T R A C T}

A field experiment was carried out on eighteen years old oil palm plantation at ICAR-

\section{Introduction}

Oil palm (Elaeis guineensis Jacq.) is an introduced crop into India for its valuable edible and industrial oil. The crop is strictly tropical in nature for its growth and development. The performance of oil palm is considered satisfactory in areas endowed with hot and humid tropical climate with optimal temperatures ranging between $80-90^{\circ} \mathrm{F}$ and average annual rainfall ranging between 2000 -
$3000 \mathrm{~mm}$ with well distribution for a larger part of the year. Zhu et al., (2008) reported that plants receiving direct sunlight for minimum of 5-7 hours per day have been found very much beneficial for optimal growth and development. So, availability of adequate moisture coupled with optimum temperature has been identified as the important factors in determining the yield of oil palm. Oil palm is traditionally grown in areas where the annual rainfall exceeds 2000 $\mathrm{mm}$ with well distribution over larger part of 
the year which are observed in countries like Malaysia and Indonesia compared to other oil palm growing countries like Nigeria, Republic of Benin and Cote $d^{\prime}$ Ivorie which have a marked dry season during major part of the year. Irrigation trials conducted in these countries on the performance of oil palm have shown positive response to irrigation in terms of growth and yield. Water availability in the soils of oil palm plantation plays an important role for its proper growth (Henson and Harun, 2005) and functions as a signal for female sex representation (Jones, 1997). In areas of water shortage, it is observed that a large number of male flowers are produced which is coupled with slow growth leading to poor yields. The basic information relating to water stress responses in oil palm is a prime topic of the day which should be investigated further for screening of tolerant lines for water deficit coupled with their physiological efficiency. Water deficit is a major abiotic stress, which is widely distributed worldwide over 1.2 billion hectares, especially in the rain-fed areas (Chaves and Oliveira, 2004; Kijne, 2006 and Passioura, 2007). Application of irrigation water as supplemental dose has been reported by several workers to increase the yield of fresh fruit bunches (Gawankar et al., 2003; Rao, 2009; Gajbhiye et al., 2011 and Sanjeevraddi et al., 2014). Keeping all these things in view the present investigation has been planned to investigate the influence of methods of irrigation water in conjunction with evapotranspiration based level of irrigation using crop factors with the intension of maximizing the yield of fresh fruit bunches and understanding the physiological responses of photosynthetic pigments in increasing the yield of fresh fruit bunches.

\section{Materials and Methods}

The present investigation was carried out on the existing eighteen years old oil palm plantation planted at ICAR-Indian Institute of
Oil Palm Research, Pedavegi, Andhra Pradesh and was laid out in split-plot design with four replications consisting of main plot treatments with two different methods of irrigation systems and three sub-plot treatments of irrigation levels using crop factors based on the rate of evapotranspiration. The level of irrigation water using crop factor was calculated as described below.

Water requirement of a crop is the quantity of water required by the crop in a given period of time for its optimum growth under field conditions. It is a function of rainfall, soil water reserves and evapotranspiration. Water requirement varies from place to place depending on climatic conditions like sunshine hours, temperature, relative humidity, wind velocity, etc. This is the best available method to estimate crop water requirement from direct measurement of evapotranspiration. In this method, pan evaporation or penman's estimate of evaporation is multiplied by an appropriate crop factor. Water use of crop is very closely related to evaporation. In fact, crop water use is composed of evaporation of water from the soil surface and transpiration of water through the leaves. Combined together these two factors are named as evapotranspiration. While evaporation is easily measured, transpiration is not. Therefore, it is much simpler to relate the crop evapotranspiration to daily evaporation via a crop factor. A crop factor is related to the per cent of ground covered by the crop canopy and therefore will vary depending on the crop stage. For an adult oil palm 0.7 is considered as crop factor. The following simple method of calculation has been devised based on the evaporation rates prevailing in the area especially during summer months (Rao et al., 2016).

Evaporation from open pan: $6.70 \mathrm{~mm}$ (for example) 
Crop factor: 0.7

Potential evapotranspiration $(\mathrm{PE})=$ Pan evaporation $\times$ Crop factor

$\mathrm{PE}=6.07 \times 0.7=4.69 \mathrm{~mm} / \mathrm{day}$

$46,900 \mathrm{~L} /$ day/ha as $1 \mathrm{~mm}$ of rainfall is equal to $1 \mathrm{~L} \mathrm{~m}^{-2}$

Since 143 palms are accommodated in one hectare area, the quantity of water per palm per day works out to be 328 litres.

Water holding capacity at not less than $70 \%$ of the field capacity is acceptable and will not affect the FFB yield of oil palm significantly.

Therefore the minimum quantity of water to be applied will be:

$4.69 \mathrm{~mm} \times 70 \%=3.283 \mathrm{~mm} /$ day or 32,830 lit./ha/day or 220 lit./palm/day.

The two methods of irrigation systems adopted were micro-jet and drip, while the three irrigation levels used based on Crop Factor (CF) were $0.6,0.7$ and 0.8. The treatments were: $\mathrm{T}_{1}$ : Micro-jet method of irrigation system using irrigation level crop factor 0.6; $\mathrm{T}_{2}$ : Micro-jet method of irrigation system using irrigation level crop factor 0.7; $\mathrm{T}_{3}$ : Micro-jet method of irrigation system using irrigation level crop factor $0.8 ; \mathrm{T}_{4}$ : Drip method of irrigation system using irrigation level crop factor $0.6 ; \mathrm{T}_{5}$ : Drip method of irrigation system using irrigation level crop factor $0.7 ; \mathrm{T}_{6}$ : Drip method of irrigation system using irrigation level crop factor 0.8 .

Chlorophyll content index value of oil palm leaves was measured by using a hand held chlorophyll content meter CCM-200 (OptiSciences, Inc., Hudson, USA) in the present study. The instrument has $0.71 \mathrm{~cm}^{2}$ measurement area and calculated as chlorophyll content index value based on absorbance measurements at 653 and $931 \mathrm{~nm}$. Five measurements with hand held meter were recorded on each leaf disc of $500 \mathrm{~cm}^{2}$ and mean of these values was used for analysis. The result was expressed as 'Chlorophyll value'. Chlorophyll-a, b and total chlorophyll contents and carotenoids content were measured as per the procedure explained by Hiscox and Israelstan (1979). All the other growth and yield parameters were recorded as per the time schedule framed. Number of leaves produced per palm were recorded on quarterly basis and expressed as per palm per year. On the selected palms the first opened leaf was marked with red color at the beginning of the first quarter and the first opened leaf in the next quarter was marked with yellow color, thus the number of leaves between the two markings indicated the number of leaves produced during that particular quarter. The number of male and female inflorescences produced between the $9^{\text {th }}$ to $17^{\text {th }}$ leaves were recorded at quarterly interval and expressed as number of male and female inflorescences produced per palm per year. Number of Fresh Fruit Bunches (FFBs) per palm were recorded in every harvest and expressed on yearly basis as number of fresh fruit bunches per palm per year. Total fresh fruit bunch weight of the palm was recorded per palm in each harvest and average of all harvests of the palms in the treatment is expressed as kilograms per palm per year. Average yield of fresh fruit bunches per palm in each treatment was multiplied with number of palms per hectare and expressed in tonnes. The data thus arrived was subjected to statistical analysis as per the procedure outlined by Panse and Sukhatme (1985).

\section{Results and Discussion}

The data pertaining to chlorophyll content index of oil palm leaves (Table 1) has indicated non-significant differences with different methods of irrigation. Significant 
differences were observed in the chlorophyll content index of oil palm leaves with different levels of irrigation using crop factors. Among the levels of irrigation treatments using crop factor 0.8 has recorded significantly highest chlorophyll content index value (126.25), whereas, level of irrigation using crop factor 0.6 has recorded significantly lowest chlorophyll content index value (94.68). Interaction effect between methods of irrigation and levels of irrigation using crop factors was found non-significant. However, application of irrigation water using crop factor 0.8 through drip method of irrigation recorded significantly highest chlorophyll content index (127.96), whereas, significantly lowest chlorophyll content index (93.88) was observed by application of irrigation water using crop factor 0.6 through micro-jet method of irrigation. The data indicated that an increase in the level of irrigation using crop factor has increased the chlorophyll content index but no significant differences were observed between the methods of irrigation. Similar kind of result was reported earlier by Sumesh et al., (2014) in transgenic Hevea lines and is found in agreement with the present result.

Significantly highest chlorophyll-a content was observed in the leaves of oil palm irrigated through drip method of irrigation (2.38 $\left.\mathrm{mg} \mathrm{g}^{-1} \mathrm{FW}\right)$, similarly, palms irrigated at crop factor 0.8 recorded significantly highest chlorophyll-a content (2.33 $\left.\mathrm{mg} \mathrm{g}^{-1} \quad \mathrm{FW}\right)$. Interaction effect between palms irrigated at different methods and levels of irrigation was also found significant. Significantly highest chlorophyll-a content $\left(2.66 \mathrm{mg} \mathrm{g}^{-1} \mathrm{FW}\right)$ was observed in the oil palm leaves irrigated through drip at crop factor 0.6, whereas, significantly lowest content of chlorophyll-a (1.41 $\mathrm{mg} \mathrm{g}^{-1} \mathrm{FW}$ ) was recorded in palms irrigated by micro-jets at crop factor 0.6.

Significantly highest chlorophyll-b content (0.46 $\mathrm{mg} \mathrm{g}^{-1} \mathrm{FW}$ ) was recorded by palms irrigated through micro-jets. Among the levels of irrigation, significantly highest chlorophyllb content $\left(0.47 \mathrm{mg} \mathrm{g}^{-1} \mathrm{FW}\right)$ was recorded in palms irrigated at crop factor 0.6 and was found at par with palms irrigated at crop factor 0.7. Interaction effect between palms irrigated at different methods and levels of irrigation was found non-significant. However, highest chlorophyll-b content $\left(0.60 \mathrm{mg} \mathrm{g}^{-1} \mathrm{FW}\right)$ was observed in the leaves of palms irrigated through micro-jets at crop factor 0.7, whereas, lowest chlorophyll-b $\left(0.25 \mathrm{mg} \mathrm{g}^{-1} \mathrm{FW}\right)$ was observed in the leaves of oil palm irrigated through drip method at crop factor 0.8 .

Significantly highest total chlorophyll content (2.73 $\mathrm{mg} \mathrm{g}^{-1} \mathrm{FW}$ ) was observed in the leaves of oil palm irrigated through drip method. Palms irrigated at crop factor 0.7 recorded highest total chlorophyll (2.70 $\left.\mathrm{mg} \mathrm{g}^{-1} \mathrm{FW}\right)$ among different irrigation levels. Interaction effect between palms irrigated at different methods and levels of irrigation water was found significant. Significantly highest total chlorophyll content (3.11 $\left.\mathrm{mgg}^{-1} \mathrm{FW}\right)$ was observed in the leaves of oil palm irrigated through drip at crop factor 0.6, whereas, significantly lowest total chlorophyll content (1.90 $\left.\mathrm{mg} \mathrm{g}^{-1} \mathrm{FW}\right)$ was observed in the leaves of oil palm irrigated through micro-jets at crop factor 0.6. Chlorophyll-a, chlorophyll-b and total chlorophyll contents are considered as the most essential pigments which are virtually necessary for the oxidative conversion of solar energy into the stored chemical energy. From the physiological perspective, the leaf chlorophyll content (for example, how it varies both between and within the species) is therefore a parameter of significant interest in its own right. The accessory pigments viz., carotenoids also have a very important role in the photosynthesis.

Total carotenoids content of oil palm leaves was found non-significant in palms irrigated at different methods and levels of irrigation (Table 1). Interaction effect between palms 
irrigated at different methods and levels of irrigation was found significant. Palms irrigated through drip method at crop factor 0.6 recorded significantly highest total carotenoids content $\left(0.17 \quad \mathrm{mg} \mathrm{g}^{-1} \quad \mathrm{FW}\right)$, whereas, significantly lowest total carotenoids content $\left(0.11 \mathrm{mg} \mathrm{g}^{-1} \mathrm{FW}\right)$ was observed in the leaves of oil palm irrigated through micro-jets at crop factor 0.6. Carotenoids act as efficient antioxidants in sequencing the reactive oxygen species particularly under stress conditions. Carotenoids are de-masked during chlorophyll degradation in the chromoplast. The interaction effect between methods and levels of irrigation water showed an unambiguous trend in the total carotenoids content of oil palm leaves. This might be due to the stress created by either methods of irrigation or levels of irrigation or both. Further, it is also expected that palms might have not responded either to the methods or levels of irrigation imposed with particular reference to total carotenoids content. Suresh and Nagamani (2006) also reported similar kind of trend in the total carotenoids conetent of adult oil palms. Upadhyay (2016) also reported similar kind of observation in the areca nut seedlings.

The data with regard to number of leaves produced per palm per year (Table 2) showed non-significant differences with methods of irrigation, levels of irrigation using crop factors as well as their interaction effects between these two. Number of leaves produced per palm per year ranged between 25.48 to 25.83 irrespective of the method and level of irrigation. In any plant, development of foliage is considered to be the critical aspect of plant with response to water stress. Hsiao et al., (1985) reported that attributes of leaf growth are very sensitive to water stress. In the present study, production of number of leaves per palm per year was found less sensitive to the methods of irrigation as well as levels of irrigation using crop factors.
The data with regard to number of male and female inflorescences produced per palm per year (Table 2) was found non-significant with different methods of irrigation. However, significant differences were observed in the number of male and female inflorescences produced per palm per year with different levels of irrigation water using crop factors. Among the levels of irrigation water using crop factors 0.7 and 0.8 have recorded significantly highest number of female and male inflorescences (7.03 and 7.93 respectively) and were found at par with each other. Interaction effect between methods of irrigation and levels of irrigation using crop factors was found non-significant with regard to production of no. of male and female inflorescences. Application of irrigation water to palms has shown profound influence on the production of male and female inflorescences. Occurrence of male and female inflorescences is a result of the process of differentiation that is known to occur 27 to 35 months before anthesis and is concurrent with the process of leaf production (Hartley, 1988). Leaves and stem have a concurrence with reproductive growth. A small reduction in these two attributes due to shortage of irrigation water supply showed an amplification of inhibitory effect on the number of female inflorescences produced per palm per year which ultimately showed the effect on number of fresh fruit bunches per palm per year. Further, the tendency of male flower production is generally higher with a decrease in the availability of water particularly during the periods of differentiation of vegetative primordia to floral primordia which lead to temporal dioecism i.e., production of male inflorescences to reduce the energy cost on the reproduction. In the present study, it was observed that application of higher amounts of irrigation water has recorded lower number of male inflorescences production at the same time increased the production of number of female inflorescences. 
Table.1 Effect of methods of irrigation and levels of irrigation using crop factors on photosynthetic pigments Response to yield of oil palm

\begin{tabular}{|c|c|c|c|c|c|}
\hline Treatments & $\begin{array}{l}\text { Chlorophyll } \\
\text { content index }\end{array}$ & $\begin{array}{l}\text { Chlorophyll-a } \\
\text { (mg g }{ }^{-1} \text { FW) }\end{array}$ & $\begin{array}{l}\text { Chlorophyll-b } \\
\text { (mg g } \text { g }^{-1} \text { FW) }\end{array}$ & $\begin{array}{l}\text { Total chlorophyll } \\
\qquad\left(\mathrm{mg} \mathrm{g}^{-1} \mathrm{FW}\right)\end{array}$ & $\begin{array}{l}\text { Total carotenoids } \\
\left.\text { (mg g } \mathrm{g}^{-1} \mathrm{FW}\right)\end{array}$ \\
\hline \multicolumn{6}{|l|}{ Methods of irrigation } \\
\hline$M_{1}$ (Micro-jet method of irrigation) & 111.76 & 2.02 & 0.46 & 2.47 & 0.14 \\
\hline $\mathbf{M}_{2}$ (Drip method of irrigation) & 112.64 & 2.38 & 0.34 & 2.73 & 0.13 \\
\hline $\mathrm{LSD}_{0.05}$ & NS & 0.168 & 0.100 & 0.123 & NS \\
\hline \multicolumn{6}{|l|}{ Levels of irrigation using crop factor } \\
\hline$\left(\mathrm{L}_{1}\right)$ Crop Factor 0.6 & 94.68 & 2.03 & 0.47 & 2.51 & 3.61 \\
\hline$\left(\mathrm{L}_{2}\right)$ Crop Factor 0.7 & 115.67 & 2.23 & 0.47 & 2.70 & 5.27 \\
\hline$\left(\mathrm{L}_{3}\right)$ Crop Factor 0.8 & 126.25 & 2.33 & 0.26 & 2.60 & 5.58 \\
\hline LSD $_{0.05}$ & 4.217 & 0.153 & 0.176 & NS & 0.330 \\
\hline \multicolumn{6}{|l|}{ Interaction of $\mathbf{M} \times \mathbf{L}$} \\
\hline $\mathbf{M}_{1} \mathbf{L}_{1}$ & 93.88 & 1.41 & 0.49 & 1.90 & 3.51 \\
\hline $\mathbf{M}_{1} \mathrm{~L}_{2}$ & 116.85 & 2.16 & 0.60 & 2.76 & 4.93 \\
\hline $\mathbf{M}_{1} \mathbf{L}_{3}$ & 124.55 & 2.47 & 0.28 & 2.76 & 6.17 \\
\hline $\mathrm{M}_{2} \mathrm{~L}_{1}$ & 95.48 & 2.66 & 0.45 & 3.11 & 3.70 \\
\hline $\mathbf{M}_{2} \mathrm{~L}_{2}$ & 114.48 & 2.30 & 0.33 & 2.63 & 5.61 \\
\hline $\mathrm{M}_{2} \mathrm{~L}_{3}$ & 127.96 & 2.19 & 0.25 & 2.44 & 4.98 \\
\hline LSD $_{0.05}$ & NS & 0.245 & NS & 0.315 & 0.523 \\
\hline
\end{tabular}


Table.2 Effect of methods of irrigation and levels of irrigation using crop factors on the photosynthetic pigments Responses in terms of yield

\begin{tabular}{|c|c|c|c|c|c|c|}
\hline Treatments & $\begin{array}{l}\text { Number of } \\
\text { leaves per } \\
\text { palm }\end{array}$ & $\begin{array}{c}\text { Number of } \\
\text { male } \\
\text { inflorescences }\end{array}$ & $\begin{array}{l}\text { Number of } \\
\text { female } \\
\text { inflorescences }\end{array}$ & $\begin{array}{c}\text { Number of } \\
\text { fresh fruit } \\
\text { bunches per } \\
\text { palm }\end{array}$ & $\begin{array}{l}\text { Weight of fresh } \\
\text { fruit bunches } \\
\text { (kg/palm/year) }\end{array}$ & $\begin{array}{l}\text { Yield of fresh } \\
\text { fruit bunches } \\
\text { (t/ha) }\end{array}$ \\
\hline \multicolumn{7}{|l|}{ Methods of irrigation } \\
\hline $\mathrm{M}_{1}$ (Micro-jet method of irrigation) & 25.59 & 6.16 & 7.08 & 6.43 & 141.00 & 19.84 \\
\hline $\mathbf{M}_{2}$ (Drip method of irrigation) & 25.71 & 5.87 & 7.29 & 6.45 & 127.05 & 18.17 \\
\hline LSD $_{0.05}$ & NS & NS & NS & NS & NS & NS \\
\hline \multicolumn{7}{|l|}{ Levels of irrigation using crop factor } \\
\hline$\left(\mathrm{L}_{1}\right)$ Crop Factor 0.6 & 25.66 & 5.75 & 5.49 & 5.49 & 126.22 & 17.57 \\
\hline$\left(\mathrm{L}_{2}\right)$ Crop Factor 0.7 & 25.64 & 7.87 & 7.03 & 7.03 & 138.72 & 19.83 \\
\hline$\left(\mathrm{L}_{3}\right)$ Crop Factor 0.8 & 25.65 & 7.93 & 6.80 & 6.80 & 137.15 & 19.61 \\
\hline LSD $_{0.05}$ & NS & 0.464 & 1.100 & 1.010 & NS & 1.944 \\
\hline \multicolumn{7}{|l|}{ Interaction of M x L } \\
\hline $\mathbf{M}_{1} \mathbf{L}_{1}$ & 25.64 & 7.75 & 5.77 & 5.77 & 136.96 & 18.62 \\
\hline $\mathbf{M}_{1} \mathrm{~L}_{2}$ & 25.65 & 5.75 & 7.09 & 7.09 & 137.22 & 19.55 \\
\hline $\mathrm{M}_{1} \mathrm{~L}_{3}$ & 25.48 & 5.00 & 6.43 & 6.43 & 139.69 & 19.68 \\
\hline $\mathbf{M}_{2} \mathbf{L}_{1}$ & 25.68 & 7.50 & 5.22 & 5.22 & 115.47 & 16.51 \\
\hline $\mathbf{M}_{2} \mathbf{L}_{2}$ & 25.63 & 5.00 & 6.97 & 6.97 & 129.00 & 18.44 \\
\hline $\mathbf{M}_{2} \mathbf{L}_{3}$ & 25.83 & 5.12 & 7.16 & 7.16 & 148.44 & 21.23 \\
\hline LSD $_{0.05}$ & NS & NS & NS & NS & NS & NS \\
\hline
\end{tabular}


Gawankar et al., (2003), Gajbhiye et al., (2011) and Sanjeevraddi et al., (2014) also reported similar kind of observations in their earlier studies which were in accordance with the present results.

The data pertaining to production of number of fresh fruit bunches per palm per year (Table 2) has recorded non-significant differences between the methods of irrigation. However, application of different levels of irrigation water based on crop factors has recorded significant differences with regard to the number of fresh fruit bunches per palm per year. Significantly highest number of fresh fruit bunches per palm per year (7.03) was observed by application of irrigation water using crop factor 0.7 and was found at par with the application of irrigation water using crop factor 0.8 , whereas, significantly lowest number of fresh fruit bunches per palm per year (5.49) was recorded by application of irrigation water using crop factor 0.6. Interaction effect between methods of irrigation and levels of irrigation using crop factors was found non-significant. However, application of irrigation water through drip method of irrigation using crop factor 0.8 has recorded highest number of fresh fruit bunches per palm per year (7.16), whereas, crop factor 0.6 has recorded lowest number of fresh fruit bunches per palm per year (5.22). Among the reproductive attributes, production of female inflorescences appeared to be highly sensitive to water stress showing a reduction. The number of fresh fruit bunches production per palm per year depends mainly on the number of female inflorescences produced on the palm. In the present investigation, it is clear that quantity of irrigation water applied to palm at each level is the same through different methods of irrigation. Hence, it may be concluded that method of irrigation has no significant impact on the vegetative growth of the plant as well as on the development of reproductive parts mainly formation of female inflorescences which ultimately influence the number of fresh fruit bunches formed on the palm. However, application of irrigation water at different levels using crop factor 0.7 has recorded significantly highest number of female inflorescences produced per palm per year (7.03) thereby recorded significantly highest number of fresh fruit bunches (7.03) per palm per year. Gawankar et al., (2003), Rao (2009), Gajbhiye et al., (2011) and Sanjeevraddi et al., (2014) reported similar kind of observations earlier while working on oil palm crop were found in accordance with the present results.

Data with regard to total weight of fresh fruit bunches per palm per year was found nonsignificant (Table 2) with different methods of irrigation, levels of irrigation using crop factors and their interaction effects. The data with regard to total weight of fresh fruit bunches per palm per year ranged between $115.47 \mathrm{~kg}$ to $148.44 \mathrm{~kg}$ irrespective of the method and level of irrigation. Highest total weight of fresh fruit bunches per palm per year was observed with drip method of irrigation using crop factor $0.8(148.44 \mathrm{~kg})$, whereas, lowest total weight of fresh fruit bunches per palm per year was observed with drip method of irrigation using crop factor 0.6 $(115.47 \mathrm{~kg})$. Under the conditions of lack of assured rainfall, supplement irrigation of water is considered the most potential factor of the crop inputs in increasing the growth and development of oil palm. Larsen (1981) has opined that unavailability of sufficient moisture to the plant during its growth and development led to alterations in the physiological and biochemical mechanisms thereby pre-disposing the plants to insect pests and diseases which may ultimately reduce the quantity and quality of economically important products. Assured supply of irrigation water through drip method of irrigation using crop factor 0.8 has 
increased the number of leaves produced per palm per year (Table 2) which has led to an increase in the photosynthetic rate. Thus increased production of photo-assimilates led to an increase in the total weight of the fresh fruit bunches by irrigating through drip method of irrigation using crop factor 0.8 . Rao (2009) in his earlier study has reported similar kind of observation in oil palm which was in accordance to the present investigation.

The data pertaining to yield of fresh fruit bunches per palm per year (Table 2) has recorded non-significant differences between the methods of irrigation. However, application of different levels of irrigation water has recorded significant differences with regard to yield of fresh fruit bunches per palm per year. Among the levels of irrigation, significantly highest annual yield of fresh fruit bunches (19.83 t/ha) was observed by application of irrigation water using crop factor 0.7 and was found at par with the application of irrigation water using crop factor 0.8. Significantly lowest annual yield of fresh fruit bunches per palm per year was observed by application of irrigation water using crop factor 0.6 (17.57 t/ha). Interaction effect between methods of irrigation and levels of irrigation using crop factors on the annual yield of fresh fruit bunches was found non-significant. Although, highest annual yield of fresh fruit bunches $(21.23 \mathrm{t} / \mathrm{ha})$ was recorded by drip method of irrigation using crop factor 0.8 it was not significantly higher than drip method of irrigation using crop factor 0.7. Lowest annual yield of fresh fruit bunches (16.51 t/ha) was observed with drip method of irrigation using crop factor 0.6. Number of fresh fruit bunch production in oil palm depends upon the number of productive female inflorescences produced. A small reduction in the number of leaves produced due to shortage of water showed an amplification of inhibitory effect on the number of female inflorescences produced thereby a reduction was observed in the number of fresh fruit bunches per palm per year which ultimately led to a reduction in the annual yield of fresh fruit bunches. A small shortage in the application of irrigation water to the palms showed a reduction in the number of female inflorescences produced (Table 2) accordingly the number of fresh fruit bunches produced was influenced which led to a reduction in the annual yield of fresh fruit bunches per palm per year. Gawankar et al., (2003) and Rao (2009) also reported similar kind of observations in their earlier studies on oil palm which supports the present investigation.

As the level of irrigation increased it showed a positive correlation with fresh fruit bunch yield of palm in terms of production of decreased number of male inflorescences, increased number of female inflorescences accordingly increased the number of fresh fruit bunches which might be due to the increased photosynthetic efficiency of the palm which is directly linked to the yield of fresh fruit bunches.

\section{References}

Chaves, M.M and Oliveira, M.M. 2004. Mechanisms underlying plant resilience to water deficits: prospects for water saving agriculture. Journal of Experimental Botany. 55: 2365-84.

Gajbhiye, R.C., Gawankar, M.S., Arulraj, S and Patil, S.L. 2011. Evaluation of drought tolerant oil palm genotypes for their performance in Konkan Region of Maharashtra. Journal of Plantation Crops. 39(1): 161-63.

Gawankar, M.S., Devmore, J.P., Jamadagni, B.M., Sagvekar, V.V and Hameedkhan, H. 2003. Effect of water stress on growth and yield of tenera oil palm. Journal of Applied Horticulture. 5(1):39-40.

Hartley, C.W.S. 1988. The Oil Palm, Third Edition. Harlow, England, Longman. 
Henson, I.E and Harun, M.H. 2005. The influence of climatic conditions on gas and energy exchanges above a young oil palm stand in north Kedah, Malaysia. Journal of Oil Palm Research. 17: 73-91.

Hiscox, J.D. and Israelstam, G.F. 1980. A method for the extraction of chlorophyll from leaf tissue without maceration. Canadian Journal of Botany. 57: 1332-34.

Hsiao, T.C., Silk, W.K and Jing, J. 1985. Leaf growth and water deficits. Biophysical effect. In: Control of leaf growth. Baker, N.R. W.J. Davies and C.K. Ong (Eds.) Cambridge University Press, Cambridge. 239-66.

Jones, L.H. 1997. The effect of leaf pruning and other stresses on sex determination in the oil palm and their representation by a computer simulation. Journal of Theoretical Biology. 187: 241-60.

Kijne, J.W. 2006. Abiotic stress and water scarcity: Identifying and resolving conflicts from plant level to global level. Field Crops Research. 97: 3-18.

Larsen, B.J. 1981. Drought resistance and water relations in conifers in relation to the nutrient. Pot Rev., 11, subj. 22, 28th Suite. $1-5$.

Panse, V.G. and Sukhtame, P.V. 1985. Statistical methods for agricultural workers. Indian Council of Agricultural Research, New Delhi.

Passioura, J. 2007. The drought environment: physical, biological and agricultural perspectives. Journal of Experimental Botany. 58: 113-17.

Rao, B.N., K. Suresh, S.K. Behera, K.
Ramachandrudu and K. Manorama, 2016. Irrigation management in oil palm (Technical Bulletin). ICAR-IIOPR, Pedavegi, Andhra Pradesh.

Rao, K.K. 2009. Effect of different methods of irrigation and nutrient requirement on yield of oil palm. International Journal of Oil Palm Research. 6(1):31-34.

Sanjeevraddi. G., Patil, D.R., Maheshwarappa, H.P., Arulraj, S., Mastan Reddy, B.G and Chandravathi, B. 2014. Evaluation of African oil palm germplasm for drought tolerance. Journal of Plantation Crops. 42(2): 170-74.

Sumesh, K.V., Satheesh, P.R., Sreelatha, S., Ravichandran, S., Thulasee dharan, A., Jayashree, R., Krishnakumar, R., Annamalainathan, K., Singh, M and Jacob, J. 2014. Drought tolerance in MnSOD transgenic Hevea brasiliensis in a dry subhumid environment. Journal of Plantation Crops. 42(1): 70-77.

Suresh, K and Nagamani, C. 2006. Variations in photosynthetic rate and associated parameters with age of oil palm leaves under irrigation. Photosynthetica. 44(2): 309-11.

Upadhyay, R.K. 2016. Does salinity stress amend the morphology and physiological appearance of young betel nut (Areca catechu L.) seedlings? Journal of Plantation Crops. 44 (2): 129-31.

Zhu, X.C, Sun, Z.M, Tao, Y.Q, Gao, W.H, Huang, Q.A, Cang, Z.W and Zhou, X.W. 2008. Introduction of prior variety of Elaeis guineensis from Malaysia. Guangdong Forest Science Technology. 24: 84-86.

\section{How to cite this article:}

Chandra Surya Rao, M., B.N. Rao, V. Vijaya Bhaskar, K. Suresh and Kalpana, S. 2018. Influence of Different Methods and Levels of Irrigation on Photosynthetic Pigments in Relation to Yield of Oil Palm (Elaeis guineensis Jacq.). Int.J.Curr.Microbiol.App.Sci. 7(02): 26-35. doi: https://doi.org/10.20546/ijcmas.2018.702.005 